\title{
Modelling the Impacts of Rainwater Tanks on Sanitary Sewer Overflows
}

\author{
$\underline{\text { T. Nasrin }}^{\text {a }}$, N. Muttil ${ }^{\text {a, b }}$ and A.K. Sharma ${ }^{\text {a, b }}$ \\ ${ }^{a}$ College of Engineering and Science, Victoria University, PO Box 14428, Melbourne, VIC, 8001, Australia; \\ ${ }^{b}$ Institute for Sustainability and Innovation, Victoria University, PO Box 14428, Melbourne, VIC, 8001, \\ Australia. \\ Email: tasnim.nasrin@live.vu.edu.au
}

\begin{abstract}
Recent studies have demonstrated that the Water Sensitive Urban Design (WSUD) strategies are sustainable, innovative and cost-effective approaches for managing stormwater runoff in urban developments. Such runoff from excessive rainfall can cause sewer system overflows. It is well established that intense rainfall increases flow into the sewer system and this increased flow is called rainfall-derived infiltration and inflow (RDII). RDII is the increased portion of sewer flows which enter the sewer network as inflow due to flooding of yard gully taps, roof downpipes illegally connected to the sanitary sewers, broken manhole covers and cross-connections between stormwater and sewer pipes. These excessive flows can also enter the sewer network as infiltration, where stormwater runoff filters through the soil and then enters the sewer pipes via damaged pipes, leaky joints and defective manhole walls. Intense rainfall events (especially of short duration) are becoming more frequent and intense in recent years. Increasing intensity will lead to more RDII. This in turn will lead to more frequent occurrences of sanitary sewer overflows (SSOs).
\end{abstract}

According to various studies, there are different types of WSUD approaches available, which include rainwater tanks, rain gardens, bio-retention cells, infiltration trenches, porous pavements and vegetative swales. These WSUD approaches can reduce sewer overflows by managing excess stormwater runoff that enters the sewer network during intense storm events. However, few studies have analyzed the role of WSUD approaches on reducing sewer overflows. Therefore, rainwater tank as one of the popular WSUD approaches has been used for this study. This paper presents a detailed hydraulic modelling with rainwater tanks to quantify the impacts of WSUD approaches for SSO reduction. Rainwater tank captures roof runoff which reduces surface stormwater runoff during a storm event. Thus, it reduces the amount of RDII into the sewer networks.

In this study, four different rainwater tank capacities are considered: 500L, 1000L, 1200L and 1500L. In addition, the impact of drain time on the sewer overflow volumes and peak overflow rates is also investigated. Drain time $(T)$ is the time required to drain out the depth of the stored water in the rainwater tank. A residential area in Glenroy, Melbourne, has been taken as the case study to illustrate the rainwater tank modelling results. The analysis indicates that rainwater tanks can reduce SSO volumes by a maximum of $31 \%$ and can reduce peak overflow rates by $30 \%$ (for the $1500 \mathrm{~L}$ tank with a drain time of 36 hours). This study has also evaluated the cost efficiency of the rainwater tanks based only on the capital cost of rainwater tanks. Thus, the approach used in this study will help water professionals to consider rainwater tanks as a mitigation strategy for controlling SSOs.

Keywords: $\quad$ SSO reduction, RDII, water sensitive urban design (WSUD), rainwater tank 


\section{INTRODUCTION}

Rainfall trends indicate that short duration intense rainfall events (with durations of 12, 18, 30 and 60 minutes) have become more frequent in recent years (Yilmaz and Perera, 2014). The Intergovernmental Panel on Climate Change (IPCC) addressed this increase as a consequence of global climate change (IPCC, 2007). Researchers such as Berggren et al., (2011) and Semadeni-Davies et al., (2008) pointed out the risk of widespread urban flooding and sewage overflow hazards due to this increase combined with the increase in urbanization (resulting in more impervious areas). This paper focuses on the impacts of intense rainfall events on the performance of the sewer network.

Intense rainfall causes an increase in rainfall-derived infiltration and inflow (RDII) into the aging sewer network. Sanitary sewers are designed to accommodate RDII flows. Due to the intense rainfall events, RDII flows exceed the capacity of the system. Thus RDII may lead to Sanitary Sewer Overflows (SSOs), which have a detrimental impact on human health and the environment (Karuppasamy and Inoue 2012; Zhang, 2007). In proposing mitigation strategies to reduce SSOs, it is necessary to have a better understanding about the sources of RDII. Inflow is the stormwater entering the sewer pipes through direct connections: roof downpipes which are illegally connected to the sanitary sewers, broken manhole lids and frames, and crossconnections between stormwater and sewer pipes. On the other hand, infiltration is the runoff that filters through the soil and then enters the sewer network. Sources of infiltration include cracked pipe sections, defective joints and damaged manhole walls (Zhang, 2007). A previous study was undertaken with a detailed RDII analysis which includes determination of the RDII flows for a case study sewer network in Glenroy, Melbourne, Australia (Nasrin et al., 2013).

This study aims to develop mitigation strategies for reducing intense rainfall-induced sewer overflows. Mitigation strategies are developed based on their sustainability and cost-effectiveness. Earlier studies have recommended selecting Water Sensitive Urban Design (WSUD) strategies as sustainable and cost-effective approaches for managing stormwater runoff. Various studies have suggested different types of sustainable WSUD approaches: rainwater tanks, rain gardens, bio-retention cells, porous pavements, green roofs, infiltration trenches and vegetative swales (Yazdanfar and Sharma, 2015; Myers et al., 2014). These techniques are also known with different terminologies: low impact development (LID), sensitive urban design system (SUDS) and, most recently, green infrastructure (Walsh et al., 2014). However, WSUD approaches are commonly used for stormwater management. Common approaches of SSO mitigation strategies focus largely on structural actions which include replacing sewers, increasing pump stations and maximizing storage capacity by retention or detention storage (Roldin et al., 2012). But these WSUD approaches can capture excess stormwater runoff which enters the sewer network during intense rainfall events (Liao et al., 2015; Shamsi, 2011; Abi Aad et al., 2009). These studies discussed the impacts of WSUD approaches for reducing sewer overflow volumes and peak overflow rates.

As stated earlier, rainwater tank has been used in this study to assess its impact on SSOs. Rainwater tank is one of the widely-used WSUD approaches in Australia. It is a popular on-site stormwater rainwater collection method which stores water for non-potable reuse or outdoor uses such as watering gardens (Rahman et al., 2012; Imteaz et al., 2012). It is usually placed beneath roof downspouts, which captures roof runoff and thus reduces surface stormwater runoff during a storm event. However, this study has applied rainwater tanks to quantify the benefits of WSUD approaches for SSO reduction. Hence, the study has investigated the hydraulic performance of a case study sewer network with four different rainwater tank capacities during intense rainfall events. The selected case study is the same sewer network in Glenroy, Melbourne, Australia. A detailed hydraulic modelling has been performed with four different sizes of rainwater tanks to analyze the performance of the sewer network during a wet year. The chosen wet year was 2010, which was identified by the Australian Bureau of Meteorology (BoM) as the third wettest year on record for Australia (BoM Australia, 2015). This analysis is expected to be beneficial to the relevant water authorities in order to develop and target mitigation strategies for controlling SSOs.

\section{WSUD APPROACHES IN PCSWMM}

In this study, PCSWMM has been used for the hydraulic modelling of the sewer network with WSUD approaches. PCSWMM uses the stormwater management model (SWMM) as its basic engine and it can be modeled on five common types of WSUD approaches (Rossman, 2010; Shamsi, 2011). These WSUD approaches are programmed into SWMM based on algorithms and can be accessed through simple dialog boxes (Rossman, 2010). Various parameters need to be added as input for the simulation. .The five types are described as follows. 
- Bio-retention cells - these acts as depression storages which contain vegetation layers over an engineered soil mixture. There is a gravel bed underneath the vegetation. These bio-retention cells provide storage, infiltration and evaporation of direct rainfall and surface runoff. Rain gardens and green roofs are similar forms of bio-retention cells.

- Rainwater tanks/ rain barrels - these are like storage tanks which capture direct rainfall and roof runoff during intense rainfall events. Rainwater tanks are usually placed beneath roof downspouts, and store stormwater runoff during a rainfall event.

- Porous pavements - these are excavated areas where gravel is used to fill the area. Here, porous concrete or asphalt mix is used for paving the surface. Stormwater runoff can pass through the paved surface and enter the gravel storage zone beneath the pavement. After that, runoff can easily infiltrate into the natural soil.

- Infiltration trenches - these are narrow ditches where gravel is also used to fill the area. They provide storage and capture runoff from the impervious area. The captured runoff then infiltrate into the natural soil.

- Vegetative swales - these are depressed areas which act as channels to route the surface runoff. Grass or vegetation is used to cover the sliding slopes of the depression areas. Vegetative swales help to reduce the conveyance capacity of stormwater runoff and provide sufficient time to infiltrate the stormwater into the natural soil.

As stated earlier, this study has applied rainwater tanks as WSUD approaches for mitigating the impacts of SSOs. The detailed outcomes of the hydraulic modelling including the description of the case study sewer network are presented in the following sections.

\section{THE CASE STUDY AREA}

The selected case study sewershed area is a residential suburb in Glenroy, which comes under the jurisdiction of the water retailer company Yarra Valley Water. This area is serviced by a separate sewer and a stormwater drainage system. The total contributing sewershed area of the catchment is $6.88 \mathrm{~km}^{2}$ and has 3750 sewer connections. The length of major sewer pipes is approximately $3.2 \mathrm{~km}$. The pipe material is concrete. The main reason for choosing this particular area as the case study is that it has one of Melbourne's aging sewer networks. The main sewer pipes are quite old so it is expected that the conduits have cracks and joint defects. Hence, RDII would be

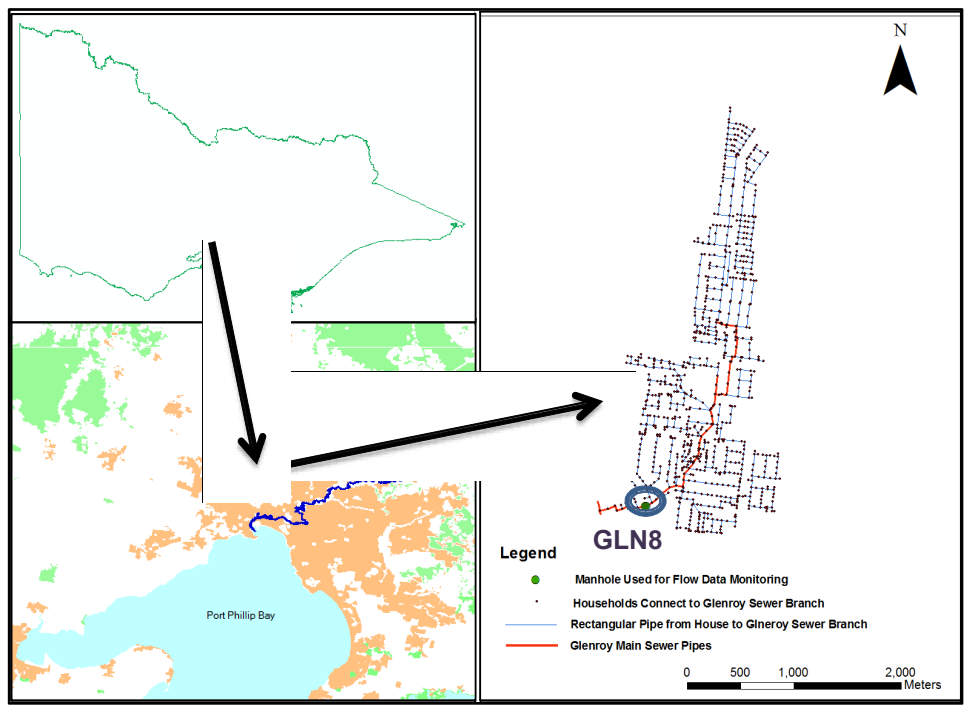

Figure 1. Case study sewershed in Melbourne. the major contributor for SSO and surcharge problems. One downstream manhole, GLN8, was used to measure sewer flow data at six minutes time-steps during the period November-December, 2010. Six minutes resolution rainfall data were obtained from the Bureau of Meteorology, Australia for a nearby rain gauge station. The total rainfall in 2010 was $681.2 \mathrm{~mm}$. There were several intense rainfall events in 2010 . The location of the study area and the layout of Glenroy sewer network with the downstream flow meter (GLN8) are shown in Figure 1.

This case study sewer network was used in another study for identifying the impacts of intense rainfall on the performance of the sewer network. A detailed hydraulic modelling of the sewer network was performed for evaluating the hydraulic performance of the existing network for this wet year, 2010. The sewer model was calibrated and validated based on measuring sewer flow data at the downstream flow meter location, GLN8 
for the wet months of November-December, 2010. After calibration and validation, the model conducted a continuous simulation for evaluating the hydraulic performance of this existing network under intense rainfall events. Various indicators were used to assess the performance of the sewer network in terms of SSOs and manhole surcharges. The hydraulic analysis indicates that the network fails to cope with intense rainfall events. As a result for the wet year, $23.01 \times 10^{3} \mathrm{~m} 3$ of volume of sewage overflowed in 2010 . These significant amounts of sewage would have led serious aesthetic, environmental and health problems for this residential catchment.

The hydraulic model of the sewer network was used as the basis for this current study. This paper focuses a detailed hydraulic modelling with four different sizes of rainwater tanks for the same sewershed area. A continuous simulation of the sewer model was again undertaken with four rainwater tank capacities for the year 2010. The outcomes of this hydraulic model quantify the benefits of WSUD approaches. The detailed modelling task is described in the next section.

\section{MODELLING OF RAINWATER TANKS FOR SSO REDUCTION}

\subsection{Characteristics of Rainwater Tanks}

In this study, four nominal rainwater tank capacities have been used to quantify the impacts of WSUD approaches for reducing sewer overflows. These are 500L, 1000L, 1200L and 1500L. According to Rossman (2010) and Abi Aad et al., (2009), PCSWMM/SWMM assumes rainwater tanks to be convex cylindrical shapes. Therefore, the effective area of the rainwater tank has been calculated by the ratio of the volume of the rainwater tank to the height of the tank.

Table 1 presents the rainwater tank parameters used in PCSWMM for the WSUD modelling.

Within PCSWMM model, the under drain outflow from a rainwater tank has been governed by the submerged orifice equation (Walsh et al., 2014). The outflow is defined as the unit depth per time and estimated by Eq. (1). In this equation, $C$ defines Table 1. Rainwater tank parameters used in PCSWMM

\begin{tabular}{llllll}
\hline Volume $(\mathrm{L})$ & & $500 \mathrm{~L}$ & $1000 \mathrm{~L}$ & $1200 \mathrm{~L}$ & $1500 \mathrm{~L}$ \\
\hline Height $(D)(\mathrm{mm})$ & & 500 & 900 & 900 & 1200 \\
\hline $\begin{array}{l}\text { Drain Coefficient } \\
(C)(\mathrm{mm} / \mathrm{hr})\end{array}$ & $\mathrm{T}=36$ Hours & $\mathrm{C}=6.26$ & $\mathrm{C}=8.39$ & $\mathrm{C}=8.39$ & $\mathrm{C}=9.69$ \\
\cline { 2 - 6 } & $\mathrm{T}=24$ Hours & $\mathrm{C}=9.39$ & $\mathrm{C}=12.59$ & $\mathrm{C}=12.59$ & $\mathrm{C}=14.55$ \\
\cline { 2 - 6 } & $\mathrm{T}=12$ Hours & $\mathrm{C}=18.78$ & $\mathrm{C}=25.19$ & $\mathrm{C}=25.19$ & $\mathrm{C}=29.09$ \\
\hline $\begin{array}{l}\text { Drain Exponent } \\
(n)\end{array}$ & 0.5 & 0.5 & 0.5 & 0.5 \\
\hline $\begin{array}{l}\text { Drain Offset } \\
\begin{array}{l}\text { Height }\left(\mathrm{H}_{\mathrm{d}}\right) \\
(\mathrm{mm})\end{array}\end{array}$ & 0 & 0 & 0 & 0 \\
\hline $\begin{array}{l}\text { Drain Delay } \\
\text { hour) }\end{array}$ & 0 & 0 & 0 & 0 \\
\hline $\begin{array}{l}\text { Impervious area } \\
\text { treated }(\%)\end{array}$ & $24 \%$ & $24 \%$ & $24 \%$ & $24 \%$ \\
\hline
\end{tabular}

the drain coefficient,

$\mathrm{h}$ is the depth $(D), H_{d}$

is the drain offset and $n$ is the drain exponent.

$q=C\left(h-H_{d}\right)^{n}$

This under drain outflow is governed by the drain coefficient, or coefficient of discharge $(C)$ and is estimated by integrating the orifice equation, Eq. (1). The integrated equation is given in Eq. (2). Here, drain coefficient accounts for the required time $(T)$ to drain a depth of stored water $(D)$.

$C=\frac{2\left(D^{0.5}\right)}{T}$

It can be seen from the data in Table 1 that the drain coefficient $(C)$ has been estimated by Eq. (2). Drain times $(T)$ has an impact on the under drain flow. Therefore, different drain times $(T)$ have been taken in this study: 36 hours, 24 hours and 12 hours to drain 500L-1500L rainwater tanks. Based on other studies, drain exponent has been taken as 0.5 for representing under drain flow as flow through the orifice (Walsh et al., 2014; Rossman, 2010). Drain offset has been taken as zero because it was considered at the bottom of the each rainwater tank. Drain delay defines the dry hours (after the rainfall events) required to open the outlet 
orifice in the rainwater tank. In this study, drain delay has been considered as zero assuming a continuously draining rainwater tank. The stormwater from the outlet pipe can be routed to lawn areas.

There is another parameter in Table 1 denoted as impervious area treated (\%). This represents roof impervious, whose runoff will collect through the rainwater tank. Rainwater tanks are used to capture roof runoff and roofs represent $24 \%$ of the total impervious area. Therefore, the impervious area treated would be $24 \%$. The above-mentioned four different sizes of rainwater tanks were installed at each house in the sewershed area. Hence, the numbers of replicate units in the model are based on the numbers of total households: 3750 . Another point to note is that the overflow and under drain flow of the rainwater tank has been routed to the pervious area of the sewershed. This represents that the roof runoff will route to the lawn areas.

\section{RESULTS AND DISCUSSION}

\subsection{Rainwater Tanks Simulations}

The outcomes of the sewer modelling with different rainwater tanks during 2010 are presented in Figures 2 and 3. Figure 2 compares the annual overflow volume after applying rainwater tanks with four different capacities in each household in the case study area. On the other hand, Figure 3 compares peak overflow rates for the different tanks. In both these figures, a comparison is made with the base case (which is the current condition without implementing rainwater tanks).

This study also sought to investigate the impact of different drain times on the sewer overflow volumes and peak overflow rates. Accordingly, three different drain times $(T=36,24$ and 12 hours) were investigated. Figures 2 and 3

also present the impact of different drain times on the reduction in overflow volume and peak overflow rates, respectively.

The sewer network's performance shows that an overflow volume of $23.01 \times 10^{3} \mathrm{~m}^{3}$ occurred for the base case. As seen in Figure 2, in comparison to the base case,

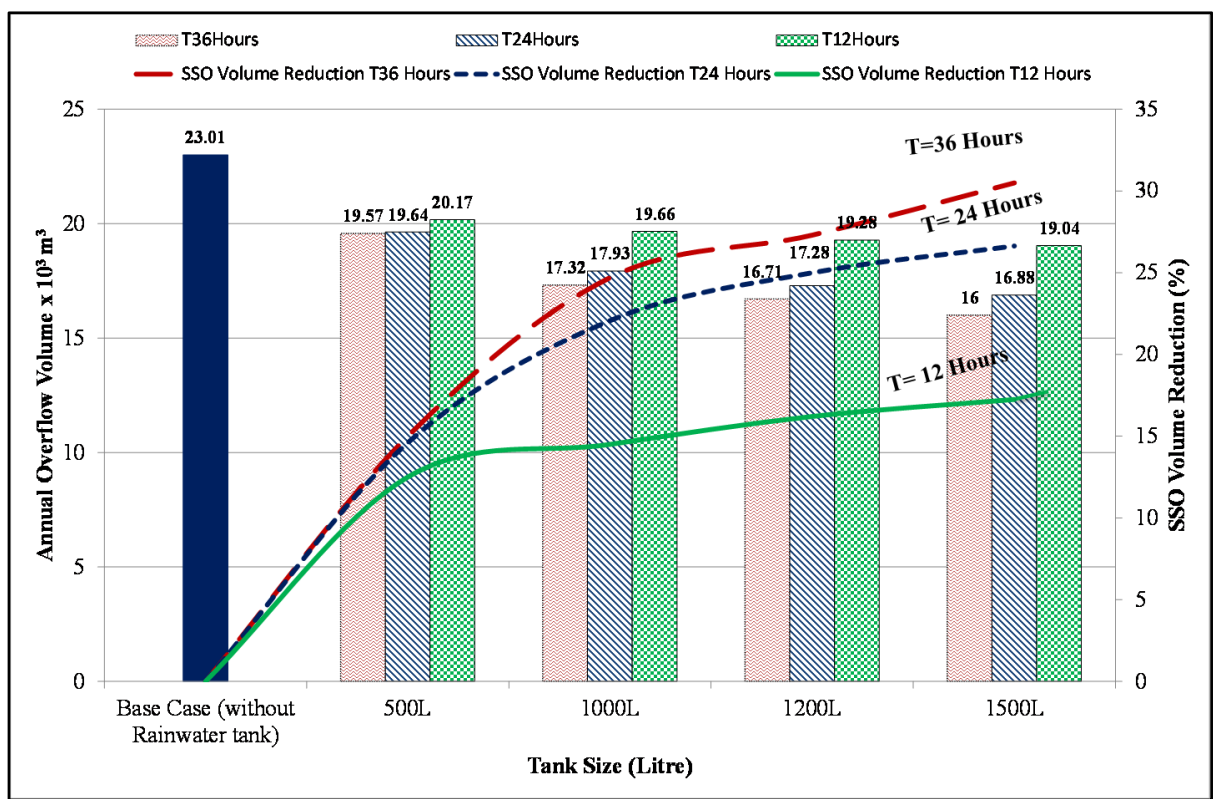

Figure 2. Annual SSO volumes and the percentage reduction in SSO volume for different tank sizes and drain times.

the $500 \mathrm{~L}, 1000 \mathrm{~L}, 1200 \mathrm{~L}$ and $1500 \mathrm{~L}$ rainwater tanks have reduced the SSO volumes by $15 \%, 25 \%, 27 \%$ and $31 \%$ respectively for the drain time $(T)$ of 36 hours. The results indicate that the increase in drain time increases the SSO volume reduction (\%) for a constant tank size, with the 1500L rainwater tank with a drain time of 36 hours provides the maximum SSO volume reduction.

Furthermore, the peak overflow rates presented in Figure 3 indicate a value of $0.4 \mathrm{~m}^{3} / \mathrm{sec}$ for the base case. After implementing the rainwater tanks in each household, it is again observed that the drain time of 36 hours 
leads to the maximum reduction in peak overflow rate as compared to the base case, although decrease in drain times also leads to a marginal decrease in peak overflow rates.

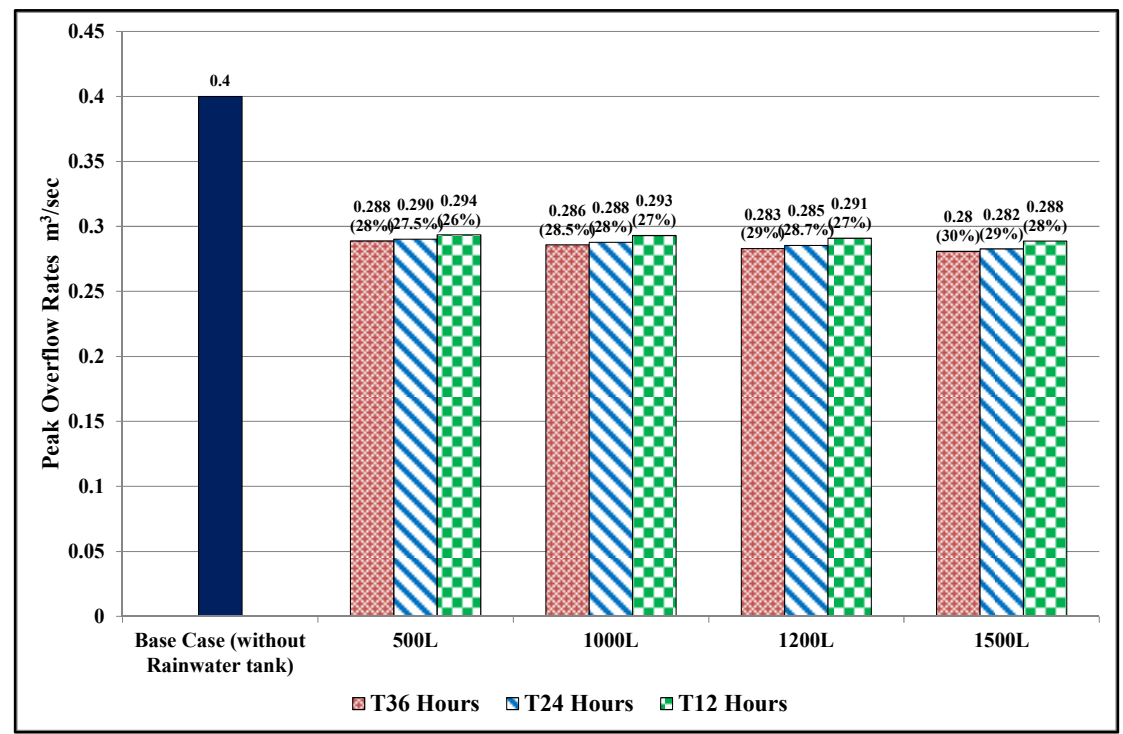

Figure 3. Peak overflow rates for different tank sizes and drain times (values in brackets are reduction in overflow rates in comparison to the base case).

\subsection{Cost Estimation of Rainwater Tank}

The cost of a rainwater tank depends on many factors including the tank size, material and location. In this study, small rainwater tanks have been implemented for the WSUD modelling.

The cost of the rainwater tanks have been estimated based on past studies, discussions with local professionals and standard rainwater tank prices available online. The estimated cost of the rainwater tanks are given in Table 2. In this study, only the Table 2. Rainwater tank cost estimation.

\begin{tabular}{lllll}
\hline $\begin{array}{l}\text { Tank } \\
\begin{array}{l}\text { Size } \\
(\mathrm{L})\end{array}\end{array}$ & $\begin{array}{l}\text { Cost } \\
(\$ A U D)\end{array}$ & $\begin{array}{l}\text { Total Number } \\
\text { of Replicate } \\
\text { Units }\end{array}$ & $\begin{array}{l}\text { Total } \\
\text { (Million) }\end{array}$ & Cost \\
\hline 500 & $\$ 250$ & 3750 & 0.93 \\
\hline 1000 & $\$ 356$ & 3750 & 1.3 \\
\hline 1200 & $\$ 400$ & 3750 & 1.5 \\
\hline 1500 & $\$ 500$ & 3750 & 1.8 \\
\hline
\end{tabular}
capital cost (i.e., the cost of the tank) is considered. The installation and maintenance costs have not been considered. A further study will be undertaken to provide a detailed life-cycle cost analysis of the rainwater tanks.

\section{CONCLUSIONS}

Intense rainfall has an adverse impact on the performance of the sewer network by causing SSOs and manhole surcharges. RDII is a major contributor for the rainfall-induced sewer overflows. Therefore, this study has sought to evaluate the impacts of WSUD approaches on reducing the sewer overflow volumes and peak overflow rates during intense rainfall events.

This study has undertaken a detailed hydraulic modelling with four different rainwater tank capacities: 500L, $1000 \mathrm{~L}, 1200 \mathrm{~L}$ and $1500 \mathrm{~L}$ and three different drain times ( $T=36,24$ and 12 hours). It can be seen from the results that the $500 \mathrm{~L}$ rainwater tank can reduce SSO volumes by up to $15 \%$ whereas the $1500 \mathrm{~L}$ reduces it by $31 \%$ when compared to the base case. The analysis indicates that an increase in rainwater tank capacity linearly increases the reduction of the SSO volumes and peak overflow rates. The analysis also indicates that drain time has an impact on the reduction of overflow volumes, but it has little impact on the reduction of peak overflow rates. In addition, this study also evaluates the cost efficiency of the rainwater tanks based only on the capital cost of rainwater tanks. A future study will undertake a detailed life-cycle cost analysis for evaluating the cost efficiency of the rainwater tanks. The capital cost analysis indicates that implementing small rainwater tanks may also be beneficial for reducing RDII. In summary, this analysis will be expected to provide a decision support tool for water professionals to consider installing rainwater tanks as a sewer overflow mitigation strategy during intense rainfall events. This in turn will be beneficial for the health of the community and the environment. 
Nasrin et al., Modelling the Impacts of Rainwater Tanks on Sanitary Sewer Overflows

\section{ACKNOWLEDGMENTS}

The authors thank Yarra Valley Water and the Bureau of Meteorology for providing the necessary data.

\section{REFERENCES}

Abi Aad, M. P., M. T. Suidan, and W. D. Shuster (2009). Modeling techniques of best management practices: Rain barrels and rain gardens using EPA SWMM-5. Journal of Hydrologic Engineering, 15(6), 434-443.

Berggren, K., M. Olofsson, M. Viklander, G. Svensson, and A. M. Gustafsson (2011). Hydraulic impacts on urban drainage systems due to changes in rainfall caused by climatic change. Journal of Hydrologic Engineering. 17(1), 92-98.

BoM, Australia. (2015). http://www.bom.gov.au/climate/enso/lnlist (Retrieved 05.05.15).

Core Writing Team, R.K. Pachauri and A. Reisinger (eds.). (2007). IPCC 2007: Climate Change 2007: Synthesis Report. Contribution of Working Groups I, II and III to the Fourth Assessment Report of the Intergovernmental Panel on Climate Change. IPCC, Geneva, Switzerland, https://www.ipcc.ch/pdf/assessmentreport/ar4/syr/ar4 syr frontmatter.pdf. (Retrieved 05.05.15)

Imteaz, M.A., A. Rahman and A. Ahsan (2012). Reliability analysis of rainwater tanks: A comparison between South-East and Central Melbourne. Resources, Conservation and Recycling, 66 (2012), 1-7.

Karuppasamy, E. and T. J. Inoue (2012). Application of USEPA SSOAP Software to sewer system modeling. World Environmental and Water Resources Congress@ @ sCrossing Boundaries, ASCE, 3494-3504.

Myers, B, D. Pezzaniti, D. Kemp, S. Chavoshi, , M. Montazeri, , A. Sharma, P. Chacko, GA. Hewa, G. Tjandraatmadja and S. Cook (2014). Water Sensitive Urban Design Impediments and Potential: Contributions to the Urban Water Blueprint (Phase 1). Goyder Institute for Water Research Technical Report Series, (14/19). http://www.goyderinstitute.org/uploads/GoyderWSUD-Task-3-Final-report FINAL-web.pdf.

Liao, Z. L., G. Q. Zhang, Z. H., He, Y. Wu, and H. Chen, (2015). Combined sewer overflow control with LID based on SWMM: an example in Shanghai, China. Water Science and Technology, 71(8), 1136-1142.

Nasrin, T., H. D. Tran, and N. Muttil (2013). Modelling impact of xxtreme rainfall on sanitary sewer system by predicting rainfall derived infiltration/inflow. In MODSIM 2013: 20th International Congress on Modelling and Simulation, Adelaide, Australia, 1-6 December 2013. http://www.mssanz.org.au/modsim2013/L12/nasrin.pdf.

Rahman, A., J. Keane and M. A. Imteaz (2012). Rainwater Harvesting in Greater Sydney: Water Savings, Reliability and Economic Benefits. Resources, Conservation and Recycling, 61 (2012), 16-21.

Roldin, M., O. Fryd, J. Jeppesen, O. Mark, P. J. Binning, P. S. Mikkelsen and M. B. Jensen (2012). Modelling the impact of soakaway retrofits on combined sewage overflows in a $3 \mathrm{~km} 2$ urban catchment in Copenhagen, Denmark. Journal of Hydrology, 452, 64-75.

Rossman, L. A (2010). Storm water management model user's manual, version 5.0. National Risk Management Research Laboratory, Office of Research and Development, U.S. Environmental Protection Agency (U.S. EPA), Cincinnati, $\mathrm{OH}$.

Shamsi, U. M. (2011). Modeling to quantify the LID benefits for CSO reduction. In 5th EWRI National Low Impact Development Conference and Low Impact Development Symposium: Greening the Urban Environment, co-hosted by the University of Villanova, North Carolina State University and University of Maryland College Park, Philadelphia.

Semadeni-Davies, A. C. Hernebring, G. Svensson and L. G. Gustafsson (2008). The impacts of climate change and urbanisation on drainage in Helsingborg, Sweden: Combined sewer system. Journal of Hydrology, 350 (1), 100-113.

Walsh, T. C., C. A. Pomeroy and S. J. Burian (2014). Hydrologic modeling analysis of a passive, residential rainwater harvesting program in an urbanized, semi-arid watershed. Journal of Hydrology, 508, 240-253.

Yazdanfar, Z., and A. K. Sharma (2015). Urban Drainage System Planning and Design- Challenges with Climate Change and Urbanization: A Review. Water Science and Technology. http://dx.doi.org/10.2166/wst.2015.207.

Yilmaz, A.G., and B.J.C. Perera (2014). Extreme rainfall nonstationarity investigation and intensity-frequencyduration relationship. Journal of Hydrologic Engineering, 19(6), 1160-1172.

Zhang, Z. (2007). Estimating rain derived inflow and infiltration for rainfalls of varying characteristics. Journal of Hydraulic Engineering. 133(1), 98-105. 